\title{
Water Conservation in Afghanistan
}

\author{
Abdullah Aini \\ Rural Engineering Coordinator Swedish Committee for Afghanistan (SCA)
}

Afghanistan is a landlocked country in Central Asia having arid and semi-arid climates with precipitation from $75 \mathrm{~mm}$ per year in the plain area to $1,170 \mathrm{~mm}$ in the highland area. Forests cover only $2 \%$ of the country and deforestation is progressing rapidly. If precautionary measures are not taken in 15 years the country will have little forest. To measure natural resources of the country, the government established 31 stations to collect meteorological information and 140 stations to record water conditions in different locations of the country. Out of 140 water stations, 40 were selected for sediment transport measurement.

Water is a precious material for human beings with different uses such as for domestic use, industrial use and agricultural production is increasing. Water utilization in Afghanistan is mostly for agriculture and approximately $85 \%$ of the country's crops are produced under irrigation systems. Irrigation systems in Afghanistan use mostly traditional methods and distribute water in traditional ways throughout the country with $84.6 \%$ of irrigation water being tapped from rivers. Water from springs and Karezes make up 7.9\% and 7\% of irrigation water, respectively. A small amount $(0.5 \%)$ of water is tapped from Arhats (dug wells).

Due to 25 years conflict in Afghanistan all infrastructures including irrigation related structures have been damaged or completely destroyed. Since 1980 there is no information about water resources in the country. On the other side the country has suffered from continuous drought for the last six years. Ground water levels have dropped considerably and affected Karezes to be dry or have reduced water. All reports related to water resources have been lost during the 25 years of conflict.

After the new government was elected in 2001, the government gave first priorities to security and communication system of the country and rebuilt $2,500 \mathrm{~km}$ of pre-war paved highways. Less work on rehabilitation of natural resources has been done so far. As per reports prepared by FAO and the Ministry of Water and Power under the Afghan government, the total annual [DT1] precipitation in the country is 180,000 million $\mathrm{m}^{3}$ $\left(150,000\right.$ million $\mathrm{m}^{3}$ from snow and 30,000 million $\mathrm{m}^{3}$ from rain). Meanwhile the total discharge of all rivers is 84,000 million $\mathrm{m}^{3}(47 \%)$ of the total precipitation in the country.

A total of $12 \%$ of the land in the country is arable, whereas only $50 \%$ of this area is irrigated per year due to shortages of water for irrigation and the other $50 \%$ will be irrigated next year. Out of total discharge produced in the country, only 55,000 million $\mathrm{m}^{3}(65 \%)$ is used within the country. The remaining leaves the country. According to a Ministry of Water and Power report, a total of 2,000 million $\mathbf{M}^{3}$ is used for domestic water supply.

There are a limited number of reservoirs to store water for irrigation and power generation. The government must develop a long-term strategy to manage water resources and reduce the effects of drought on agriculture. The strategy should focus on increasing water capital and making better use of water. The strategy should include (i) water harvesting and watershed management, more water reservoirs (small and large), (ii) effective control of ground water utilization, (iii) better information system on water availability, (iv) elimination of unsustainable land use practices, (v) improved intake structures and corresponding on-farm water management, (vi) management transfer of state owned schemes, (vii) extension of the irrigated command area. The geographical situation in the country is where water is available there is not enough land for irrigation and where land is available there is no water to fulfill the irrigation requirements.

Key words: Afghanistan, water resources management, water availability, water utilization, irrigation system, water conservation, water laws

Received: October 9, 2006, Accepted: March 24, 2007

Corresponding Author: Abdullah Aini, E-mail: aini@ncdcgroup.com 


\section{Introduction}

Afghanistan is a small mountainous, land-locked country with a surface area of $655,000 \mathrm{~km}^{2}$, situated in the central part of the Asian mainland. The climate over the most part of the country is arid and semi-arid with rainfall ranging from $75 \mathrm{~mm}$ per year in Nimroz and Farah to $1,170 \mathrm{~mm}$ per year in South Salang (Fig. 1). Approximately $85 \%$ of the land is either mountainous or desert and more than $25 \%$ of the land lies above $2,500 \mathrm{~m}$ in elevation.

Forest covers only $2 \%$ of the land in the country. Unfortunately, forests that are most important for water conservation in Afghanisatn are declining due to increasing demand for fuel wood and illegal logging to sell abroad. This decline results in a loss of approximately 30,000 ha of forest per year. If no precautionary measures are taken, Afghanistan will have little natural forest in 15 years. Local communities with the help of NGOs have attempted to protect forests, but local leaders have disrupted these efforts leading to the destruction of physical barriers.

In the country, a total of 31 locations for metrological data collection (rainfall, temperature, relative humidity, snow, wind and sunshine) were available with at least one in each province centre. For recording the water stages of each river to calculate discharge, the construction of gauging stations started in the Helmand River Basin with limited numbers in 1940s. Installation of water stage recorders in the Helmand River Basin was done by USGS. In the late 50s, the German water economy department started installation of gauging stations in the Kabul River Basin and USSR started

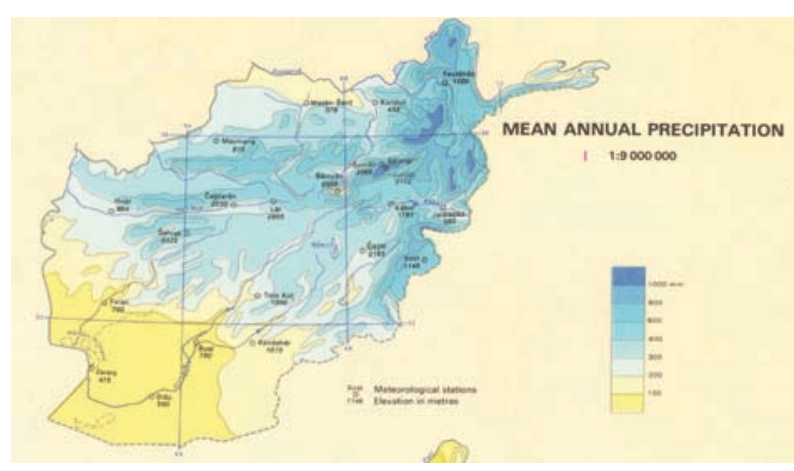

Fig. 1. Mean Annual Precipitation in Afghanistan. a few gauging stations on the North flowing rivers including Amu Darya. During the 60s all gauging stations came under the Water and Soil Survey Department of the government. Totally 140 gauging stations to record water stages were established on river systems all over the country. Only 131 were equipped by automatic water stage recorders and the remaining were equipped with staff gauges to be read manually three times a day. Of 140 gauging stations, 40 key gauging stations were selected for collecting information regarding sediment transport of the rivers systems either periodically or daily. Most of the daily sediment transport gauging stations were at the inlet of the existing dams or key locations where there was a possibility of future dam construction.

Water is essential for different uses such as domestic, industral and agricultural. The world population is increasing rapidly and the demand for water is also increasing to meet these requirements for different uses. On the other hand considering the importance of water needs for human life, the $\mathrm{UN}$ announced the $80 \mathrm{~s}$ as the water decade for the world. Water utilization and conservation is the most crucial issue to be taken into consideration for the different uses of water. Any further positive steps toward effective water utilization, conservation and management will benefit the next generation of the world.

\section{Irrigation Systems used in Afghanistan}

The agriculture sector in Afghanistan relies considerably on irrigation systems both traditional and modern that tap water from rivers and streams. Approximately $85 \%$ of all crops are produced under irrigation systems. The irrigation systems in Afghanistan are traditional and in very poor condition with approximately $25 \%$ efficiencies, where the norm for efficient irrigation systems is $40 \%$. The following irrigation systems are commonly in use:

1. Modern and relatively large scale irrigation systems mainly tap water from the rivers either by direct diversion of water or by construction of dams to store water. These systems are limited to a few governmental projects in Helmand, Kandahar, Nangarhar, Ghazni and Parwan provinces. A few more projects were under construction before 
Table 1. Major Modern Irrigation Systems in Afghanistan.

\begin{tabular}{|c|c|c|c|c|c|}
\hline Name & Province & Command Area in Ha. & Donor & Year Const. & Const. $\%$ \\
\hline Helmand and Arghandab & $\begin{array}{l}\text { Helmand } \\
\text { Kandahar }\end{array}$ & 103,000 & USA & $19940-50$ & 100 \\
\hline Parwan & Parwan & 24,800 & China & 1960 & 100 \\
\hline Nangarhar & Nangarhar & 39,000 & Former USSR & 1960 & 100 \\
\hline Kelagai & Baghlan & 20,000 & GoA & 1970 & 100 \\
\hline Gawargan & Baghlan & 11,000 & ADB \& GoA & 1978 & 70 \\
\hline Kunduz-Khanabad & Kunduz & 30,000 & WB & 1980 & 80 \\
\hline Sardeh & Ghazni & 15,000 & Former USSR & 1980 & 90 \\
\hline Salma & Herat & 115,000 & WAPCOS & 1976 & 20 \\
\hline Total & & 357,800 & & & \\
\hline
\end{tabular}

1978 in Baghlan, Kunduz, Nimroz and Herat provinces, but they are not yet completed. For details see Table 1.

2. Temporary or locally built diversion structures over perennial and semi-perennial rivers to convey water through canals/ streams (Jui) to land for irrigation.

3. Diversion structures over seasonal rivers and stream beds to convey flood waters to the fields whenever it rains. This system also is known as Sailabi or flooding.

4. Karezes (Qanat in old literature) are the most widely used irrigation systems in the South part of the Hindu Kush ranges from Kabul to Herat.

5. Spring water where available is conveyed by gravity to land for irrigation.

6. Dug wells (Arhat) are a very old method in which animals (donkey, horse or camel) are used to draw water by a series of buckets going up and down from a large dug well approximately $5 \mathrm{~m}$ in diameter and up to $5 \mathrm{~m}$ deep.

The Ministry of Water and Power under the Government of Afghanistan divided the sources of irrigation water into four classes: rivers $(84.6 \%)$, springs (7.9\%), Karezes (7\%) and Arhat (0.5\%) (Fig. 2).

It is worth mentioning that, the distribution of water is not uniform according to crop water requirements in a traditional method. Upstream land takes more water whereas downstream land does not get enough water for cultivation. The reasons for distribution not being uniform are improper design of outlets, lack of efficient water distribution system (water law) and weak maintenance system. The government approved a water law for the country approximately 25 years ago, but unfortunately the law was not put into practice due to its complicity and contradiction with common traditional distribution methods. Owners of land paid a huge amount of money to purchase or lease water and they will not agree to give this water to someone else without payment.

\section{Present Status of Water Resources}

Before 1978, Afghanistan was self-sufficient in cereal production and a flourishing horticulture market provided about $40 \%$ of the country's exports in fresh and dried fruits and nuts. During the last two and half decades of war, all infrastructures including irrigation systems in the country have been severely damaged or completely destroyed. Additionally these systems required excessive maintenance to provide a continuous supply of water. Canal intakes were washed away and excessive water has entered the canals and filled the embankments or canals with sediment. Such repeated failures were time-consuming and costly to repair. This caused interruptions in the supply of water at critical times during the irrigation season and considerable losses in crop yields. The rehabilitation of these systems, in terms of ability to supply greater quantities of water and distribute it with minimum losses are crucial issues to be immediately taken into consideration.

During the 80s and 90s international communities rushed to help Afghans rehabilitate their 


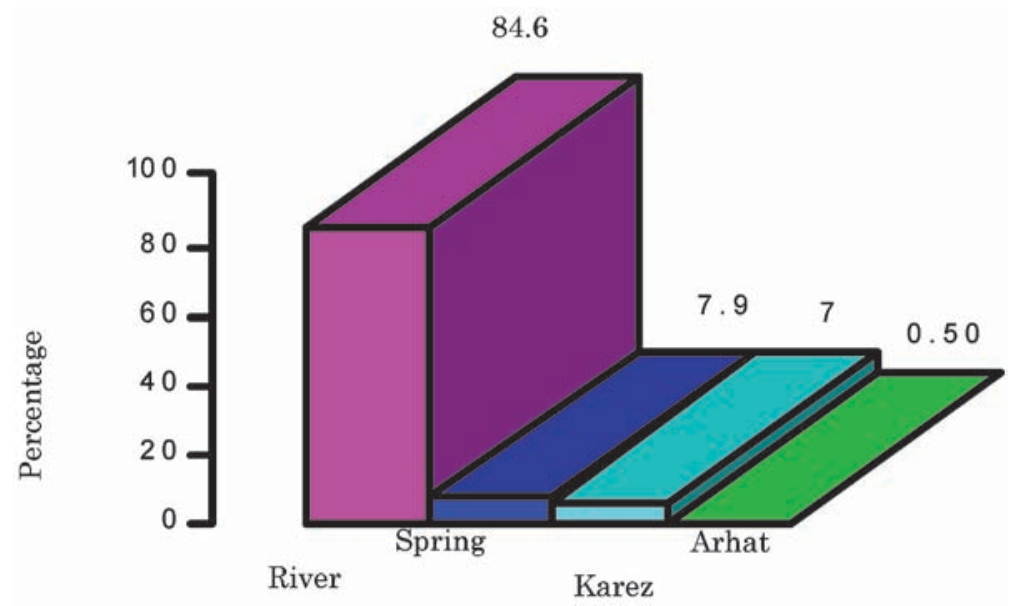

Fig. 2. Irrigation Water Sources.

irrigation systems. These assistances were on an emergency basis and their main tasks were to clean the Karezes and canals. It rarely happened that water intakes were designed and constructed by a few NGOs, but due to lack of design based on flood information the construction washed out within one flood season. The farmers were not satisfied with these jobs and wanted permanent structures to get enough and continuous water for their irrigation.

The recording network of all river systems collapsed and all 140 hydrological gauging stations were destroyed completely. Most of the hydrological year books printed by the hydrology department were lost. Recording processes continued in the country until 1980 and then due to distortion of gauging stations in the river basins it stopped. Since 1980, there is not a single station to record water stages of the river in the country and so far the concerned departments have made no action to reinstallation gauging stations.

During the last six years drought hit Afghanistan and the demands for water greatly increased so rich farmers tried to find another source of water for their agriculture. As a result they drilled deep wells and drew ground water for their irrigation. This resulted in a considerable drop (up to $10 \mathrm{~m}$ ) in the groundwater table, especially in the south part of the country. Dropping of the groundwater level has resulted in dryness and reductions in discharge of Karezes.

All reports related to water resources development projects were lost due to conflict between different Afghan factions. Now most of the donor agencies are working to redo those reports and start work again from the bottom. After the Bonn agreement, a new government was established in the country and started work to prepare the constitution and obtain approval from the Afghan Loya Jirga (Supreme Council). Meanwhile the government has placed first priority on security and communication systems. The government has rebuilt approximately $2,500 \mathrm{~km}$ of the pre-war paved highways. Regarding water resources development less work has been done so far.

\section{Available Water Resources}

The river regimes in Afghanistan depend on annual rain and snow melt in highland above 2,000 $\mathrm{m}$ in elevation and represented $80 \%$ of Afghan water resources (excluding ground water) of the country. The annual water received from snowmelt in highland is estimated to be 150,000 million $\mathbf{M}^{3}$ and the rest of the country received only 30,000 million $\mathbf{M}^{3}$ through rainfall results a total of 180,000 million $\mathbf{M}^{3}$ for the whole country. Out of total runoff in Afghanistan, only 15\% contributes to recharge ground water in the country.

According to the Hydrology Department under the Ministry of Water and Power, all river systems in Afghanistan are divided into the following five basins (Fig. 3):

1. The Amu Darya Basin in the north of the country flowing from east to west.

2. The north flowing river basins that either disappear inside or outside of the country. 


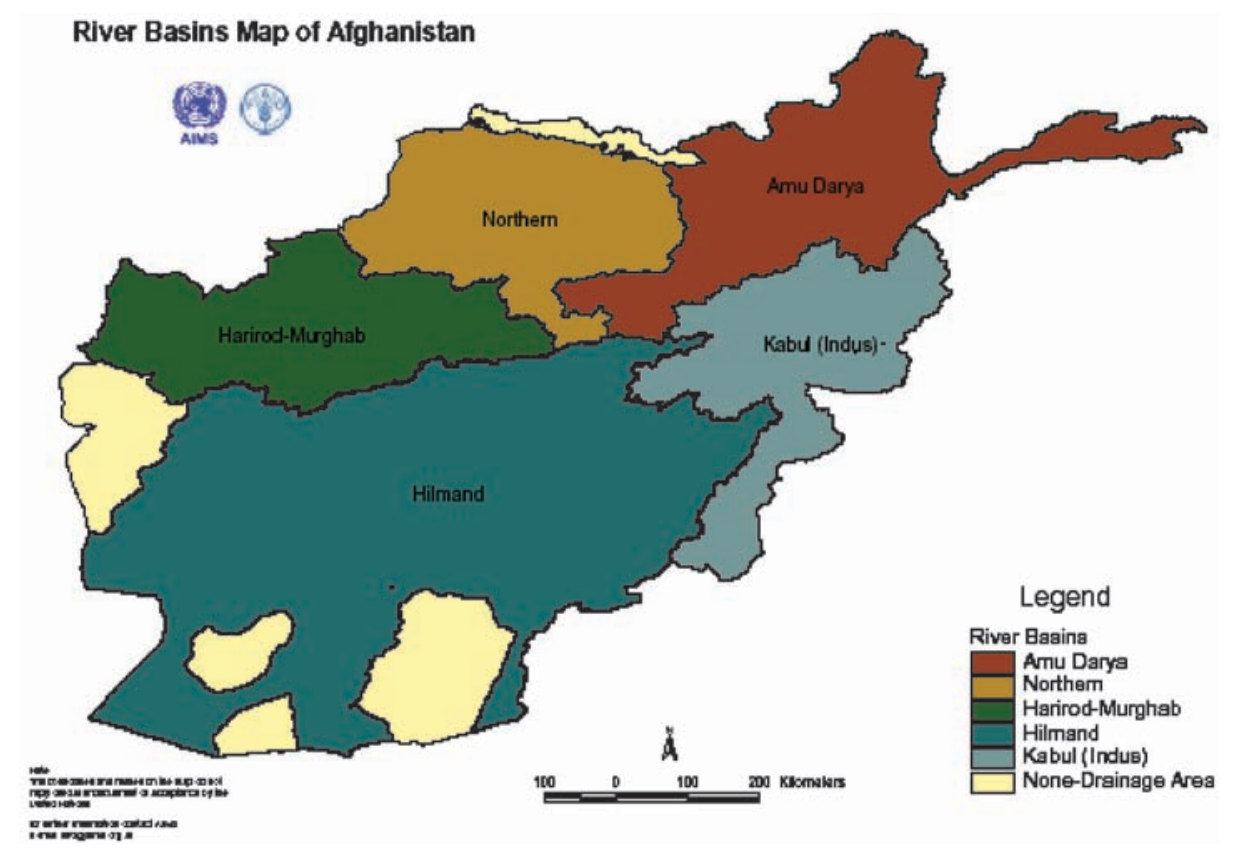

Fig. 3. River Basins in Afghanistan.

3. The Hari Rud River Basin flowing toward the west, then north and entering Turkmanistan.

4. The Helmand River Basin flowing toward the south-west and ponds in Hamun-i-Sabiri.

5. The Kabul River Basin flowing toward the east and joining the Indus River in Pakistan.

The total annual discharge of the above mentioned river basins is 84,000 million $\mathrm{M}^{3}(47 \%)$ of the total precipitation in the country. For details see Table 2.

Groundwater in Afghanistan has not been completely surveyed yet. Figures reflected in different reports are based on assumptions. The groundwater has been surveyed in a limited area, Moqur Area in Ghazni by the Ministry or Water and Power, Herat Centre by the Erkon Company from England, Har-i-Rud by the Montreal Company from Canada, Omakay in Zabul, Jerai in Kandahar and Bakwa in Farah Province jointly by WAPCOS India and WAPECA (Water and Power Engineering Company of Afghanistan). The ministry of Mine and Industry has only surveyed the Kabul area.

\section{Water Resources Utilization}

As mentioned before, the country is mountainous and only $12 \%$ of the country's land $\left(7.86 \times 10^{6}\right.$ ha) is arable. In a normal year due to shortages of water only $50 \%$ of the arable land is cultivated. Only 55,000 million $\mathbf{M}^{3}(65 \%)$ of the total discharge is used within the country. The remaining water without any use leaves the country. According to NGO and UN agency assessments water resources utilization in Afghanistan is in poor shape. Beside utilization of water resources for agriculture the government has constructed few reservoirs to store floodwater so it can be used for both irrigation and power generation. For detail of the location of dams see Table 3.

The actual capacities of the above completed dams has been considerably reduced by silt entering from the watershed during the flood season. As per a government report, the total domestic use of water is estimated to be 2,000 million $\mathbf{M}^{3}$. This figure is rough and there is no detail information on the matter. In Afghanistan, industries have not developed much yet and water use of industries has not been estimated.

\section{Water Conservation}

The construction of dams (both reservoirs and check dams) over perennial, semi-perennial and seasonal rivers, and their use for irrigation and power generation is probably the best long term solution. However, international experience has 
Table 2. Mean annual discharge for each river basin in Afghanistan.

\begin{tabular}{|c|c|c|c|c|}
\hline River Basin & River Name & River Regime & $\begin{array}{l}\text { Discharge in } \\
\text { million } \mathrm{M}^{3}\end{array}$ & $\begin{array}{c}\text { Percentage } \\
\text { of Total }\end{array}$ \\
\hline \multirow[t]{3}{*}{ Amu Darya } & Ab-i-Panja & Snow/glacier-fed & 36,420 & 43 \\
\hline & Kokcha & Snow/glacier-fed & 5,700 & 7 \\
\hline & Kunduz & Rain/Snow-fed & 6,000 & 7 \\
\hline Total Amu Darya & & & 48,120 & 57 \\
\hline \multirow[t]{5}{*}{ Kabul/Indus } & Gomal & Rain/snow-fed & 350 & 0 \\
\hline & Margo, Shamal, Khuram. & Rain/snow-fed & 400 & 0 \\
\hline & Panjshir & Rain/snow-fed & 3,130 & 4 \\
\hline & Kunar & Snow/glacier-fed & 15,250 & 18 \\
\hline & Kabul, itself & Rain/snow-fed & 2,520 & 3 \\
\hline Total Kabul/Indus & & & 21,650 & 26 \\
\hline \multirow[t]{5}{*}{ Northern Rivers } & Khulm & Rain/snow-fed & 60 & 0 \\
\hline & Balkhab & Rain/snow-fed & 1,650 & 2 \\
\hline & Ab-i-Safid & Rain/snow-fed & 40 & 0 \\
\hline & Shirin Tagab & Rain/snow-fed & 100 & 0 \\
\hline & Amu Darya desert & Rain/snow-fed & 30 & 0 \\
\hline Total Northern & & & 1,880 & 2 \\
\hline \multirow[t]{11}{*}{ Helmand } & Farah Rod & Rain/snow-fed & 1,250 & 1 \\
\hline & Adraskan Rod & Rain/snow-fed & 210 & 0 \\
\hline & Khuspas Rod & Rain/snow-fed & 40 & 0 \\
\hline & Khash Rod & Rain/snow-fed & 170 & 0 \\
\hline & Kaj Rod & Rain/snow-fed & 60 & 0 \\
\hline & Ghazni Rod & Rain/snow-fed & 350 & 0 \\
\hline & Helmand at Kajaki dam & Rain/snow-fed & 6,000 & 7 \\
\hline & Musa Qala Rod & Rain/snow-fed & 220 & 0 \\
\hline & Arghandab & Rain/snow-fed & 820 & 1 \\
\hline & Lower Helmand & Rain/snow-fed & 110 & 0 \\
\hline & Southern river & Rain/snow-fed & 70 & 0 \\
\hline Total Helmand & & & 9,300 & 11 \\
\hline \multirow[t]{3}{*}{ Har-i-Rod } & Murghab & Rain/snow-fed & 1,350 & 2 \\
\hline & Kashan and Kushk Rod & Rain/snow-fed & 110 & 0 \\
\hline & Har-i-Rod & Rain/snow-fed & 1,600 & 2 \\
\hline Total Har-i-Rod & & & 3,060 & 4 \\
\hline Grand Total & & & 84,010 & 100 \\
\hline
\end{tabular}

shown that the river basin is not only the best unit for planning but also for management of both water supply and demand, and conservation of natural resources. The geographical situation in Afghanistan is where water is available there is not enough land to irrigate, i.e. Kabul and Kunar are major rivers based on annual discharge, but both flow in a long narrow valley and cross the Afghanistan border near Torkham to join the Indus River in Pakistan. Where land is available there is not enough water to fulfill the irrigation requirements, i.e. the Helmand River with its tributaries flows in a large plain area and joins the Hamon-i-Sabiri between Afghanistan and Iran. These limitations 
Table 3. Dams.

\begin{tabular}{l|l|c|l}
\hline \hline \multicolumn{1}{c|}{ Name } & Province & Storage in $10^{6} \mathrm{~m}^{3}$ & \multicolumn{1}{|c}{ Purpose or use } \\
\hline Kajaki & Helmand & 2,700 & For irrigation \& power, completed. \\
Arghandab & Kandahar & 479 & For irrigation, completed. \\
Salma & Herat & 900 & Irrigation \& power, but not completed \\
Naghloo & Kabul & 450 & Power, completed \\
Sardeh & Ghazni & 164 & Irrigation, completed \\
Daroonta & Nangarhar & 120 & Irrigation and power, completed. \\
\hline Total & & 4,813 & \\
\hline
\end{tabular}

result in inefficient use of the available water resources. The government has to develop a longterm strategy to manage water resources and reduce the effects of drought on agriculture. The strategies should focus on increasing water capital and making better use of water. These strategies should include (i) water harvesting and watershed management, including more water reservoirs (small and large), (ii) effective control of ground water utilization, (iii) better information system on water availability, (iv) elimination of unsustainable land use practices, (v) improved intake structures and corresponding on-farm water management, (vi) management transfer of state owned schemes, (vii) extension of the irrigated command area.

\section{Conclusion}

\subsection{Short-Term Programmes}

Over the short term the emphasis of the strategies and opportunities will be on investment in the rehabilitation of traditional small and medium irrigation schemes, with such programmes to play a key role in institutional restructuring and capacity building, planning for the rehabilitation of formal and large-scale schemes, establishing database and information systems, and initiating the institutional change process. More detailed provisions include:

1. Conduct water conservation and harvesting through soil, vegetation and forest cover management by constructing check dams, control bunds and other facilities to conserve water and enhance groundwater recharge in all watersheds.

2. Rehabilitate small to medium-scale irrigation schemes requiring infrastructural repair work that extends beyond routine preventive maintenance and requires resources that farmers and villagers are unable to mobilize.

3. The rehabilitation programmes need be based on systematic technical assessment of problems in consultation with Mirab (water master).

4. Involving the communities in the maintenance and operations is a key factor to increase agricultural productivity and outputs. Therefore, rehabilitation of these systems need be under taken within the community development framework. Pilot projects need also be implemented to support community management of watersheds and water harvesting.

5. Plan the rehabilitation of formal and largescale irrigation schemes. Initial assessment work has to be done by MWP (Ministry of Water and Power), with schemes identified and preliminary technical assessments to be undertaken. Users will have to be organized into an appropriate institutional framework and water delivery contracts agreed upon. This will include water charging policies and collection mechanisms.

6. Database and information system establishment should commence as soon as practical. Rebuilding of the water resources knowledge base need be a collaborative effort of all core ministries and agencies, coordinated by the Afghan Information Management System (AIMS).

7. A government task force including AIMS is required to develop standards and protocols to enable efficient sharing and use of a wide range of data for different purposes. Coordination of this work by the government is essential to ensure that all studies contribute 
to the overall goal. Re-establishing the hydrological and hydro-geological network (including stations to monitor snow pack) is a high priority, though it should be undertaken within the context of earlier network design.

8. Appropriate institutional arrangements for water resource management are an essential prerequisite. These options should be assessed in the context of the broader review of required sector agencies and their respective roles.

\subsection{Medium-Term Programmes}

The medium-term interventions should involve expansion of the investment programme and implementation of institutional and policy reforms, via the following key activities:

1. Expansion of the existing traditional small and medium irrigation systems with rehabilitation programmes under community development.

2. Implementation of an investment programme for rehabilitation of formal and large-scale irrigation schemes. This rehabilitation should be based on feasibility studies for each scheme and selection criteria for prioritizing individual schemes.

3. Institutional reform and capacity building.

4. Policy and legislative reform for water policies and rights, water charges, com- munity-based watershed management and irrigation system transfer to users, and groundwater and inter-country water transfer.

5. The present water laws should be revised and established community rules should be taken into consideration to respond to both traditional and modern irrigation systems.

6. The government should take over the responsibility to protect forests and provide laws to avoid deforestation of the country.

\section{Acknowledgements}

The author would like to express his thanks to Dr. Khabir Alim, Water Engineer, IOM, Afghanistan, for his introducing me to TASAE 2006. I would also like to thank Dr. Iwasaki Yoichi, President, University of Tsukuba for his invitation to travel to Japan and participate in the TASAE 2006 conference. The author also thanks Dr. Shahmahmood, acting country director, SCA for granting me permission to attend TASAE 2006.

\section{References}

A. Aini, 1991, Irrigation systems in Afghanistan, Article published in Mujahidin Journal in Islamabad, Pakistan. Alim, A.K., 2006. Sustainability of Water Resources in Afghanistan. J. Devel. Sus. Agric. 1: 53-66.

ADB, 2003, Rebuilding Afghanistan's Agriculture Sector. FAO, Afghanistan Agriculture Strategy.

Ministry of Water and Power, 2004, Watershed ATLAS of Afghanistan. 